\title{
PENGARUH EKSTRAK DAUN JAMBU BIJI (Psidium guajava), DAUN PEPAYA (Carica papaya) DAN DAUN SIRIH (Piper betle) TERHADAP EKTOPARASIT PADA IKAN KARPER (Cyprinus carpio)
}

\section{EFFECT OF GUAVA LEAF (Psidium guajava), PAPAYA LEAF (Carica papaya) AND BETEL LEAF (Piper betle) EXTRACT ON THE ECTOPARASITE IN COMMON CARP (Cyrpinus carpio)}

\author{
Rossy Hardhini $^{\left.{ }^{*}\right)}$, Sadikin Amir ${ }^{1)}$, Dewi Nur'aeni Setyowati ${ }^{1)}$ \\ ${ }^{1)}$ Program Studi Budidaya Perairan, Universitas Mataram \\ Jl. Pendidikan N0.37 Mataram, NTB
}

\begin{abstract}
Abstrak
Indonesia adalah negara tropis yang kaya akan keanekaragaman hayati, termasuk di dalamnya adalah ikan. Upaya penanggulangan terhadap serangan penyakit dapat dilakukan melalui tindakan pencegahan maupun pengobatan. Beberapa bahan kimia yang biasa digunakan oleh para pembudidaya tidak mudah terurai secara alami, sehingga dikatagorikan tidak ramah lingkungan. Tanaman yang berpotensi untuk mencegah penyakit yaitu daun jambu biji dengan kandungan tannin, daun sirih dengan kandungan minyak atsiri dan daun pepaya dengan kandungan papain. Penelitian ini perlu dilakukan untuk mengetahui pengaruh perendaman dari ekstrak daun jambu biji, sirih dan pepaya terhadap ektoparasit pada ikan karper. Penelitian dilaksanakan sejak bulan Juli hingga Agustus 2016 di Laboratorium Basah Program Studi Budidaya Perairan, Universitas Mataram. Penelitian ini dilakukan menggunakan metode eksperimental dengan Rancangan Acak Lengkap (RAL) Faktorial dengan 2 faktor, yaitu jenis daun dan konsentrasi. Faktor jenis daun terdiri dari daun jambu biji, daun sirih dan daun pepaya, sedangkan faktor konsentrasi terdiri dari0,0 g/l, 1,0 g/l dan 1,5 g/l. Masingmasing perlakuan diulang sebanyak 3 kali sehingga diperoleh 27 unit percobaan. Data yang diperoleh dalam penelitian dianalis menggunakan sidik ragam pada taraf nyata 5\%. Hasil penelitian menunjukkan bahwa perendaman ikan karper menggunakan ekstrak daun pepaya 1,0 g/l dapat menurunkan tingkat serangan ektoparasit pada ikan karper.
\end{abstract}

Kata kunci : ikan karper, intensitas, kelangsungan hidup, pertumbuhan, prevalensi.

\begin{abstract}
Indonesia is a tropical country rich in biodiversity, including fish. Efforts to overcome the attacks of disease can be done through preventive action and treatment. Some chemicals commonly used by the farmers are not easy to decompose naturally, so categorized not environmentally friendly. Plants that have the potential to prevent disease are guava leaves with tannin content, betel leaf with essential oil content and papaya leaves with papain content. This research needs to be done to know the effect of immersion of guava leaf extract, betel and papaya on ectoparasit in carp fish. The study was conducted from July to August 2016 at the Aquaculture Laboratory, Study Program of Aquaculture, University of Mataram. This research was conducted using experimental method with Randomized Complete Design (RAL) Factorial with 2 factors, namely leaf type and concentration. Leaf type factor consists of guava leaf, betel leaf and papaya leaf, while the concentration factor consists of $0.0 \mathrm{~g} / 1$, $1.0 \mathrm{~g} / 1$ and $1.5 \mathrm{~g} / 1$. Each treatment was repeated 3 times so it was obtained 27 experimental units. The data obtained in the research was analyzed using variance at $5 \%$ real level. The results showed that soaking carp fish using papaya leaf extract of $1.0 \mathrm{~g} / 1 \mathrm{can}$ reduce the level of ectoparasitic attack on carp fish.
\end{abstract}

Keywords: common carp, intensity, survival rate, growth, prevalence

*email korespondensi: rhadhini@gmail.com 


\section{Pendahuluan}

Indonesia adalah negara tropis yang kaya akan keanekaragaman hayati, termasuk di dalamnya adalah ikan. Ikan merupakan hewan air yang mudah terinfeksi oleh patogen, seperti parasit, jamur, virus dan bakteri, terutama melalui air pada area budidaya. Kondisi sakit pada ikan terjadi sebagai akibat suatu keadaan yang mengakibatkan kondisi fisik, morfologi dan fungsi tubuh dari seekor ikan mengalami perubahan, disebabkan oleh faktor internal maupun eksternal. Contoh faktor internal adalah genetik, sekresi, imunodefisiensi, saraf dan metabolik, juga akibat kelainan anatomis. Sedangkan contoh faktor eksternal yang mengakibatkan kejadian sakit pada ikan misalnya adalah kekurangan atau kesalahan pakan, pengaruh benturan fisik dan patogen yang disebabkan oleh infeksi parasit, jamur, bakteri dan virus (Nurcahyo, 2014).

Upaya penanggulangan terhadap serangan penyakit dapat dilakukan melalui tindakan pencegahan maupun pengobatan. Upaya pencegahan dapat dilakukan diantaranya dengan cara mengontrol kualitas air agar sesuai dengan habitat asli ikan, pemberian pakan yang sesuai baik kualitas maupun kuantitasnya, sedangkan pengobatan dapat dilakukan dengan menggunakan bahan kimia atau antibiotik. Beberapa bahan kimia yang biasa digunakan oleh para pembudidaya tidak mudah diurai secara alami, sehingga dikategorikan tidak ramah lingkungan. Dampak negatif dari penggunaan antibiotik yaitu terjadinya akumulasi di dalam jaringan terutama di tulang, sehingga dapat membahayakan manusia yang mengkonsumsinya (Rosidah, 2012).

Ikan konsumsi adalah jenis-jenis ikan yang lazim dikonsumsi sebagai pangan oleh masyarakat. Ikan konsumsi dapat dikelompokkan berdasarkan habitat hidupnya, yaitu ikan konsumsi dari laut dan dari perairan di darat (air tawar). Ikan mas atau biasa disebut dengan ikan karper (Cyprinus carpio) merupakan jenis ikan konsumsi air tawar, berbadan memanjang pipih ke samping dan lunak. Ikan karper (Cyprinus carpio) sudah dipelihara sejak tahun 475 sebelum masehi di Cina. Di Indonesia, ikan karper mulai dipelihara pada tahun 1920. Ikan karper (Cyprinus carpio) yang terdapat di Indonesia merupakan ikan karper yang dibawa dari Cina,
Eropa, Taiwan dan Jepang. Ikan karper Punten dan Majalaya merupakan hasil seleksi di Indonesia (Tim Karya Tani Mandiri, 2009).

Salah satu cara yang dapat digunakan untuk meningkatkan daya tahan tubuh dan mengantisipasi infeksi parasit adalah dengan meningkatkan daya tahan tubuh ikan tersebut, namun tidak dengan senyawa kimia. Ikan yang terserang penyakit dapat disembuhkan dengan pengobatan melalui makanan, suntikan dan perendaman. Prinsip perendaman dilakukan dengan menggunakan obat-obatan ataupun bahan kimia dengan cara merendam ikan yang terkena parasit (Gusrina, 2008).

Usaha yang dapat dilakukan selain penggunaan bahan kimia yaitu dengan memanfaatkan tanaman yang sudah lama dimanfaatkan oleh manusia untuk menjaga kesehatannya, namun belum banyak diketahui efektivitasnya terhadap ikan. Tanaman yang berpotensi untuk mencegah penyakit, yaitu daun jambu biji dengan kandungan tanin, daun pepaya dengan kandungan papain yang merupakan antibakteri dan daun sirih dengan kandungan minyak atsiri sebagai antibakteri. Tujuan dilakukannya penelitian ini yaitu untuk mengetahui pengaruh perendaman ekstrak daun jambu biji, daun sirih dan daun pepaya terhadap ektoparasit pada ikan karper (Cyprinus carpio).

Penelitian ini bertujuan untuk mengetahui pengaruh ekstrak daun jambu biji, daun sirih dan daun pepaya terhadap ektoparasit pada ikan karper (Cyprinus carpio). Hasil penelitian ini diharapkan dapat memberikan informasi mengenai pengaruh ekstrak daun jambu biji, daun sirih dan daun pepaya terhadap ektoparasit pada ikan karper (Cyprinus carpio).

\section{Metode Penelitian}

Penelitian ini dilaksanakan pada bulan Juli hingga Agustus 2016 bertempat di Laboratorium Basah, Program Studi Budidaya Perairan, Universitas Mataram. Penelitian ini dilakukan menggunakan metode eksperimental dengan melakukan percobaan pemberian ekstrak daun dengan konsentrasi dan jenis daun yang berbeda. Rancangan percobaan yang dilakukan pada penelitian ini adalah Rancangan Acak Lengkap (RAL) Faktorial 
yang terdiri dari 2 faktor. Faktor yang diuji adalah jenis daun (a) dan konsentrasi (b). Faktor jenis daun (a) terdiri dari 3 taraf, yaitu daun jambu biji (a1), daun sirih (a2) dan daun pepaya (a3), sedangkan faktor konsentrasi terdiri dari 3 taraf, yaitu $0,0 \mathrm{~g} / \mathrm{l}(\mathrm{b} 1), 1,0 \mathrm{~g} / \mathrm{l}$ (b2) dan 1,5 g/l (b3). Masing- masing perlakuan diulang sebanyak 3 kali, sehingga diperoleh 27 unit percobaan.

\section{Prosedur Penelitian}

Ikan karper (Cyprinus carpio) yang digunakan memiliki ukuran 4-6 cm. Daun jambu biji, daun sirih dan daun pepaya dicuci bersih kemudian dikeringkan dalam udara terbuka selama \pm 3 hari, kemudian dioven. Setelah semua daun kering kemudian diblender hingga halus.

Pengamatan terhadap ektoparasit dilakukan sebelum perendaman ekstrak daun dan sesudah perendaman ekstrak daun. Hal ini bertujuan untuk mengetahui perbandingan tingkat serangan ektoparasit sebelum dan sesudah perendaman ekstrak daun. Kualitas air diamati 2 kali, yaitu minggu pertama dan minggu terakhir.

Identifikasi parasit dilakukan secara makroskopis dan mikroskopis. Makroskopis yaitu dilakukan dengan melihat organ-organ eksternal ikan, seperti mulut, kepala dan operculum diamati secara kasar mata. Pemeriksaan mikroskopis dilakukan dengan cara sirip, ekor, lendir dan insang diambil dan diamati di bawah mikroskop.

\section{Parameter Penelitian}

Pengamatan yang dilakukan meliputi tingkat kelangsungan hidup, pertambahan panjang mutlak, prevalensi dan intensitas. Tingkat kelangsungan hidup dihitung menggunakan rumus $\mathrm{SR}=\mathrm{Nt} / \mathrm{No} \times 100 \%$ dimana $\mathrm{Nt}=$ jumlah ikan yang hidup di akhir penelitian dan No = jumlah ikan yang hidup di awal penelitian (Syahida, 2013). Pertambahan panjang mutlak dihitung menggunakan rumus $\mathrm{L}=\mathrm{Lt}-\mathrm{Lo}$, dimana $\mathrm{Lt}=$ panjang rata-rata ikan pada waktu $\mathrm{t}(\mathrm{cm})$ dan $\mathrm{Lo}=$ panjang rata-rata ikan pada awal penelitian $(\mathrm{cm})$ (Tarigan, 2014). Tingkat prevalensi dihitung menggunakan rumus Prevalensi $=$ (jumlah ikan yang terserang : jumlah sampel yang diperiksa) x 100\%. Tingkat intensitas dihitung menggunakan rumus Intensitas $=$ (jumlah parasit yang menyerang: jumlah ikan yang terinfeksi parasit) x 100\% (Setiadi (2008).

\section{Hasil}

\section{Jenis Ektoparasit yang Ditemukan}

Hasil identifikasi yang dilakukan selama penelitian ditemukan 4 jenis ektoparasit seperti yang disajikan pada Tabel 1. Parasit yang menyerang ikan karper, yaitu parasit Trichodina sp., parasit Dactylogyrus sp., parasit Gyrodactylus sp. dan parasit Ichthyophthirius multifilis.

Tabel 1. Jenis dan lokasi ditemukannya

\begin{tabular}{|c|c|c|}
\hline No Perlakuan & Jenis Ektoparasit & Lokasi \\
\hline \multirow{4}{*}{$\begin{array}{l}1 \text { Daun } \\
\text { jambu biji }\end{array}$} & Trichodina $\mathrm{sp}$. & Sisik \\
\hline & Dactylogyrus sp. & Insang \\
\hline & Gyrodactylus sp. & Sirip \\
\hline & Ichthyophthirius & Sisik \\
\hline \multirow[t]{4}{*}{2 Daun sirih } & Trichodina sp. & Lendir \\
\hline & Dactylogyrus sp. & Insang \\
\hline & Gyrodactylus sp. & Sirip \\
\hline & Ichthyophthirius & Sisik \\
\hline \multirow[t]{4}{*}{3 Daun } & Trichodina sp. & Lendir \\
\hline & Dactylogyrus sp. & Insang \\
\hline & Gyrodactylus sp. & Sirip \\
\hline & $\begin{array}{l}\text { Ichthyophthirius } \\
\text { multifilis }\end{array}$ & Sisik \\
\hline
\end{tabular}

\section{Prevalensi Ikan Karper}

Nilai prevalensi terbesar pada parasit Dactylogyrus sp. yaitu pada perlakuan daun jambu biji 0,0 g/l dan terkecil pada perlakuan daun pepaya $1,0 \mathrm{~g} / \mathrm{l}$ Tabel 2. Dari hasil pengamatan menunjukkan bahwa pada perlakuan daun pepaya $1,0 \mathrm{~g} / \mathrm{l}$ berbeda nyata terhadap perlakuan daun jambu biji $1,5 \mathrm{~g} / \mathrm{l}$, daun sirih $1,0 \mathrm{~g} / \mathrm{l}$ dan daun pepaya $1,5 \mathrm{~g} / \mathrm{l}$, sedangkan perlakuan daun pepaya $1,0 \mathrm{~g} / \mathrm{l}$ tidak berbeda nyata terhadap perlakuan daun jambu biji $0,0 \mathrm{~g} / \mathrm{l}$, daun jambu biji $1,0 \mathrm{~g} / \mathrm{l}$ dan daun sirih 0,0 g/l. Rata-rata prevalensi Gyrodactylus sp. tertinggi pada perlakuan daun jambu biji $0,0 \mathrm{~g} / \mathrm{l}$ dan terendah pada perlakuan daun pepaya $1,0 \mathrm{~g} / \mathrm{l}$. Rata-rata prevalensi Trichodina sp. tertinggi pada perlakuan daun jambu biji $0,0 \mathrm{~g} / \mathrm{l}$, daun jambu biji $1,5 \mathrm{~g} / \mathrm{l}$, daun sirih 0,0 $\mathrm{g} / \mathrm{l}$, daun sirih $1,0 \mathrm{~g} / \mathrm{l}$, daun pepaya $0,0 \mathrm{~g} / \mathrm{l}$, sedangkan terendah pada perlakuan daun jambu biji 1,0 g/l, daun sirih 1,5 g/l dan daun pepaya $1,5 \mathrm{~g} / \mathrm{l}$. Rata-rata prevalensi tertinggi parasit Ichthyophthirius multifilis pada perlakuan daun jambu biji $0,0 \mathrm{~g} / \mathrm{l}$, daun jambu biji 1,5 g/l, daun sirih $0,0 \mathrm{~g} / \mathrm{l}$ dan daun pepaya 
1,5 $\mathrm{g} / \mathrm{l}, \quad$ sedangkan rata-rata prevalensi terendah pada perlakuan daun jambu biji 1,0 $\mathrm{g} / \mathrm{l}$, daun sirih $1,0 \mathrm{~g} / \mathrm{l}$, daun sirih $1,5 \mathrm{~g} / \mathrm{l}$, daun pepaya $0,0 \mathrm{~g} / \mathrm{l}$ dan daun pepaya $1,0 \mathrm{~g} / \mathrm{l}$.
$1,5 \mathrm{~g} / \mathrm{l}$, daun sirih $0,0 \mathrm{~g} / \mathrm{l}$, daun sirih $1,0 \mathrm{~g} / \mathrm{l}$ dan daun pepaya $0,0 \mathrm{~g} / \mathrm{l}$. Rata-rata intensitas parasit Gyrodactylus sp. terbesar pada

Tabel 2. Rata-rata Prevalensi (ind/ekor) jenis ektoparasit yang ditemukan menyerang ikan karper (Cyprinus carpio) setiap kombinasi perlakuan ekstrak dan konsentrasi ekstrak

\begin{tabular}{lcccc}
\hline \multirow{2}{*}{$\begin{array}{c}\text { Kombinasi } \\
\text { Perlakuan }\end{array}$} & \multicolumn{3}{c}{ Rata-rata Prevalensi Ektoparasit pada Setiap Perlakuan } \\
\cline { 2 - 5 } & \multicolumn{2}{c}{ Insang } & \multicolumn{2}{c}{ Permukaan tubuh } \\
\hline D. Jambu biji 0,0 g/l & $60^{\mathrm{ab}}$ & $20^{\mathrm{a}}$ & $0^{\mathrm{a}}$ & $0^{\mathrm{a}}$ \\
D.jambu biji $1,0 \mathrm{~g} / 1$ & $53^{\mathrm{ab}}$ & $6^{\mathrm{a}}$ & $0^{\mathrm{a}}$ & $0^{\mathrm{a}}$ \\
D. jambu biji 1,5 g/l & $20^{\mathrm{cd}}$ & $6^{\mathrm{a}}$ & $6^{\mathrm{a}}$ & $6^{\mathrm{a}}$ \\
D. sirih 0,0 g/l & $33^{\text {abc }}$ & $6^{\mathrm{a}}$ & $6^{\mathrm{a}}$ & $6^{\mathrm{a}}$ \\
D. sirih $1,0 \mathrm{~g} / 1$ & $26^{\mathrm{bcd}}$ & $13^{\mathrm{a}}$ & $6^{\mathrm{a}}$ & $0^{\mathrm{a}}$ \\
D. sirih $1,5 \mathrm{~g} / 1$ & $6^{\text {cd }}$ & $6^{\mathrm{a}}$ & $0^{\mathrm{a}}$ & $0^{\mathrm{a}}$ \\
D. pepaya 0,0 g/l & $33^{\text {abc }}$ & $3^{\mathrm{a}}$ & $6^{\mathrm{a}}$ & $0^{\mathrm{a}}$ \\
D. pepaya $1,0 \mathrm{~g} / 1$ & $0^{\mathrm{d}}$ & $0^{\mathrm{a}}$ & $0^{\mathrm{a}}$ & $0^{\mathrm{a}}$ \\
D. pepaya $1,5 \mathrm{~g} / 1$ & $6^{\text {cd }}$ & $6^{\mathrm{a}}$ & $0^{\mathrm{a}}$ & $0^{\mathrm{a}}$ \\
\hline
\end{tabular}

Ket: Nilai yang diikuti huruf superscript berbeda pada tiap kolom menandakan berbeda nyata

Dari hasil pengamatan menunjukkan bahwa prevalensi parasit Gyrodactylus sp., parasit Trichodina sp. dan parasit Ichthyophthirius multifilis tidak berbeda nyata setiap perlakuan. Pengaruh pemberian ekstrak daun dan konsentrasi yang berbeda terhadap parasit Dactylogyrus sp. dapat dilihat pada Gambar 1

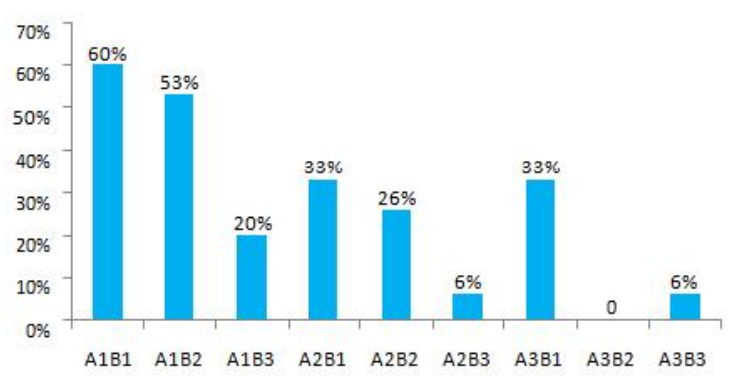

Gambar 1. Diagram pengaruh kombinasi perlakuan ekstrak daun dan konsentrasi daun yang berbeda terhadap prevalensi ektoparasit Dactylogyrus sp.

\section{Intensitas Ikan Karper (Cyprinus carpio)}

Rata-rata intensitas terbesar pada parasit Dactylogyrus sp. yaitu pada perlakuan daun jambu biji 1,0 g/l dan terkecil pada perlakuan daun pepaya 1,0 g/l (Tabel 3). Dari hasil pengamatan diketahui bahwa pada perlakuan daun sirih $1,5 \mathrm{~g} / \mathrm{l}$, daun pepaya $1,0 \mathrm{~g} / \mathrm{l}$ dan daun pepaya $1,5 \mathrm{~g} / \mathrm{l}$ berbeda nyata dengan perlakuan daun jambu biji $0,0 \mathrm{~g} / \mathrm{l}$, daun jambu biji 1,0 g/l, daun jambu biji perlakuan daun sirih $1,0 \mathrm{~g} / \mathrm{l}$ dan terkecil pada perlakuan daun pepaya $1,0 \mathrm{~g} / \mathrm{l}$. Rata-rata parasit Trichodina sp. terbesar pada perlakuan daun jambu biji 1,5 g/l dan terkecil pada perlakuan daun pepaya $1,0 \mathrm{~g} / \mathrm{l}$, sedangkan ratarata parasit Ichthyophthirius multifilis terbesar pada perlakuan daun jambu biji $0,0 \mathrm{~g} / \mathrm{l}$ dan terkecil pada perlakuan daun pepaya $0,0 \mathrm{~g} / \mathrm{l}$ dan daun pepaya $1,0 \mathrm{~g} / 1$.

\section{Tingkat Kelangsungan Hidup}

Rata-rata tingkat kelangsungan hidup (SR) pada ikan karper (Cyprinus carpio) dapat dilihat pada Tabel 4. Pada Tabel 4. menunjukkan rata-rata kelangsungan hidup ikan karper (Cyprinus carpio) yang diberikan ekstrak daun dan konsentrasi yang berbeda di akhir penelitian menunjukkan hasil yang seimbang, yaitu sekitar 60,0\% sampai 93,3\%. Sedangkan perlakuan yang tidak diberikan ekstrak daun dan konsentrasi yang berbeda menunjukkan rata-rata kelangsungan hidup ikan karper (Cyprinus carpio) 46,7\% sampai $66,7 \%$. Dari hasil penelitian menunjukkan pada perlakuan ekstrak daun pepaya konsentrasi $0,0 \mathrm{~g} / \mathrm{l}$ berbeda nyata dengan daun jambu biji 1,5 g/l, daun sirih $0,0 \mathrm{~g} / \mathrm{l}$, daun sirih $1,0 \mathrm{~g} / \mathrm{l}$, daun sirih $1,5 \mathrm{~g} / \mathrm{l}$ dan daun pepaya 1,5 $\mathrm{g} / \mathrm{l}$, namun tidak berbeda nyata dengan perlakuan daun jambu biji 1,0 gr/l, daun jambu biji $1,5 \mathrm{~g} / \mathrm{l}$ dan daun pepaya $1,0 \mathrm{~g} / \mathrm{l}$. 
Tabel 3. Rata-rata Intensitas (individu/ekor) Jenis Ektoparasit yang Ditemukan Menyerang Ikan Karper (Cyprinus carpio) pada Setiap Kombinasi dan Perlakuan Ekstrak Daun dan Konsentrasi Daun

\begin{tabular}{lcccc}
\hline \multirow{2}{*}{$\begin{array}{c}\text { Kombinasi } \\
\text { Perlakuan }\end{array}$} & \multicolumn{3}{c}{ Rata-rata Prevalensi Ektoparasit pada Setiap Perlakuan } \\
\cline { 2 - 5 } & \multicolumn{2}{c}{ Insang } & \multicolumn{2}{c}{ Permukaan tubuh } \\
\hline Dactylogyrus & Gyrodactylus & Trichodina & Ichthyophthirius \\
\hline D. Jambu biji 0,0 g/l & $1,5^{\mathrm{ab}}$ & $0,1^{\mathrm{a}}$ & $0,2^{\mathrm{a}}$ & $0,2^{\mathrm{a}}$ \\
D.jambu biji 1,0 g/l & $1,8^{\mathrm{a}}$ & $0,1^{\mathrm{a}}$ & $0,0^{\mathrm{a}}$ & $0,0^{\mathrm{a}}$ \\
D. jambu biji 1,5 g/l & $0,8^{\mathrm{bc}}$ & $0,1^{\mathrm{a}}$ & $0,3^{\mathrm{a}}$ & $0,1^{\mathrm{a}}$ \\
D. sirih 0,0 g/l & $0,7^{\mathrm{bc}}$ & $0,1^{\mathrm{a}}$ & $0,1^{\mathrm{a}}$ & $0,1^{\mathrm{a}}$ \\
D. sirih 1,0 g/l & $0,6^{\mathrm{bc}}$ & $0,3^{\mathrm{a}}$ & $0,1^{\mathrm{a}}$ & $0,0^{\mathrm{a}}$ \\
D. sirih 1,5 g/l & $0,2^{\mathrm{c}}$ & $0,2^{\mathrm{a}}$ & $0,0^{\mathrm{a}}$ & $0,0^{\mathrm{a}}$ \\
D. pepaya 0,0 g/l & $0,7^{\mathrm{bc}}$ & $0,2^{\mathrm{a}}$ & $0,1^{\mathrm{a}}$ & $0,0^{\mathrm{a}}$ \\
D. pepaya 1,0 g/l & $0,0^{\mathrm{c}}$ & $0,0^{\mathrm{a}}$ & $0,0^{\mathrm{a}}$ & $0,0^{\mathrm{a}}$ \\
D. pepaya 1,5 g/l & $0,1^{\mathrm{c}}$ & $0,1^{\mathrm{a}}$ & $0,0^{\mathrm{a}}$ & $0,1^{\mathrm{a}}$ \\
\hline
\end{tabular}

Ket: Nilai yang diikuti huruf superscript berbeda pada tiap kolom menandakan berbeda nyata

Tabel 4.Tingkat Kelangsungan Hidup Ikan

\begin{tabular}{clc}
\multicolumn{3}{c}{ Karper (Cyprinus carpio) } \\
\hline No & \multicolumn{1}{c}{ Perlakuan } & Rata-rata \\
\hline 1 & D. jambu biji 0,0 g/l & $66,7^{\mathrm{a}}$ \\
2 & D. jambu biji 1,0 g/l & $93,3^{\mathrm{a}}$ \\
3 & D. jambu biji 1,5 g/l & $93,3^{\mathrm{ab}}$ \\
4 & D. sirih 0,0 g/l & $66,7^{\mathrm{bc}}$ \\
5 & D. sirih 1,0 g/l & $73,3^{\mathrm{ab}}$ \\
6 & D. sirih 1,5 g/l & $60,0^{\mathrm{ab}}$ \\
7 & D. pepaya 0,0 g/l & $46,7^{\mathrm{b}}$ \\
8 & D. pepaya 1,0 g/l & $93,3^{\mathrm{a}}$ \\
9 & D. pepaya 1,5 g/l & $73,3^{\mathrm{ab}}$ \\
\hline
\end{tabular}

\section{Pertumbuhan}

Pertumbuhan ikan karper (Cyprinus carpio) selama penelitian dapat dilihat pada Tabel 5. Pada Tabel 5. menunjukkan hasil rata-rata panjang dan berat ikan karper (Cyprinus carpio) tidak berbeda nyata antar perlakuan daun dan konsentrasi yang berbeda (tidak signifikan). Rata-rata panjang yang tertinggi yaitu pada perlakuan daun jambu biji $0 \mathrm{~g} / \mathrm{l}$ dan daun pepaya $1,5 \mathrm{~g} / \mathrm{l}$, sedangkan rata-rata panjang terendah yaitu pada perlakuan daun jambu biji 1,0 g/l. Untuk rata- rata berat ikan karper karper (Cyprinus carpio) tertinggi pada perlakuan daun jambu biji $0 \mathrm{~g} / \mathrm{l}$ dan daun pepaya $1,0 \mathrm{~g} / \mathrm{l}$, sedangkan rata-rata berat terendah pada perlakuan daun sirih $0,0 \mathrm{~g} / \mathrm{l}$, daun sirih $1,5 \mathrm{~g} / \mathrm{l}$ dan daun pepaya $1,5 \mathrm{~g} / \mathrm{l}$.

\section{Kualitas Air}

Data kualitas air (DO, pH dan suhu) selama penelitian dapat dilihat pada Tabel 6 .
Pada Tabel 6. rata-rata suhu selama penelitian menunjukkan suhu yang relatif sama, yaitu antara $27^{\circ} \mathrm{C}$ sampai $28^{\circ} \mathrm{C}$ dimana suhu tertinggi pada perlakuan daun pepaya $0,0 \mathrm{~g} / \mathrm{l}$ dan daun jambu biji 1,0 g/l, sedangkan ratarata suhu terendah pada perlakuan daun pepaya $1,0 \mathrm{~g} / \mathrm{l}$ yaitu $28^{\circ} \mathrm{C}$.

\section{Pembahasan}

\section{Jenis Ektoparasit yang Ditemukan}

Pada penelitian menunjukkan bahwa parasit yang menyerang ikan karper Trichodina sp., Dactylogyrus sp., Gyrodactylus sp. dan Ichthyophthirius multifilis. Menurut Winaruddin (2007) parasit Trichodina sp. sering ditemukan pada bagian sirip, sisik, insang dan operculum, parasit Ichthyophthirius multifilis sering ditemukan pada bagian sisik, parasit Dactylogyrus sp. ditemukan menyerang insang dan parasit Gyrodactylus sp. sering ditemukan menyerang pada bagian sisik dan insang.

\section{Prevalensi Ikan Karper}

Pada perlakuan ekstrak daun sirih (Piper betle) nilai prevalensi dan intensitas tertinggi yaitu konsentrasi $0 \mathrm{~g} / \mathrm{l}$ dan terendah konsentrasi 1,5 g/l. Menurut Devi (2015), daun sirih (Piper betle) mengandung minyak atsiri sebanyak 4,2\%. Menurut Inayatullah (2012), daun sirih berperan dalam antibakteri terhadap bakteri Staphylococcus aureus dengan efektivitas yang tinggi, karena di dalam daun sirih mengandung minyak atsiri dengan bethel 
Tabel 5.Pertumbuhan Ikan Karper (Cyprinus carpio)

\begin{tabular}{llcc}
\hline No & $\quad$ Perlakuan & $\begin{array}{c}\text { Rata-rata } \\
\text { Panjang } \\
(\mathrm{cm})\end{array}$ & $\begin{array}{c}\text { Rata-rata } \\
\text { Berat } \\
(\mathrm{g})\end{array}$ \\
\hline 1. & D. jambu biji $0,0 \mathrm{~g} / 1$ & $1,1^{\mathrm{a}}$ & $1,4^{\mathrm{a}}$ \\
2. & D. jambu biji $1,0 \mathrm{~g} / 1$ & $0,4^{\mathrm{a}}$ & $1,2^{\mathrm{a}}$ \\
3. & D. jambu biji $1,5 \mathrm{~g} / 1$ & $0,8^{\mathrm{a}}$ & $0,8^{\mathrm{a}}$ \\
4. & D. sirih $0,0 \mathrm{~g} / 1$ & $0,6^{\mathrm{a}}$ & $0,6^{\mathrm{a}}$ \\
5. & D. sirih $1,0 \mathrm{~g} / 1$ & $0,5^{\mathrm{a}}$ & $0,6^{\mathrm{a}}$ \\
6. & D. sirih $1,5 \mathrm{~g} / 1$ & $0,5^{\mathrm{a}}$ & $0,6^{\mathrm{a}}$ \\
7. & D. pepaya $0,0 \mathrm{~g} / 1$ & $0,5^{\mathrm{a}}$ & $0,7^{\mathrm{a}}$ \\
8. & D. pepaya $1,0 \mathrm{~g} / 1$ & $1,1^{\mathrm{a}}$ & $1,4^{\mathrm{a}}$ \\
9. & D. pepaya $1,5 \mathrm{~g} / 1$ & $0,6^{\mathrm{a}}$ & $0,6^{\mathrm{a}}$ \\
\hline
\end{tabular}

Tabel 6. Kualitas air

\begin{tabular}{lccc}
\hline \multicolumn{1}{c}{ Perlakuan } & $\begin{array}{c}\text { Suhu } \\
\left({ }^{\circ} \mathrm{C}\right)\end{array}$ & pH & $\begin{array}{c}\text { DO } \\
(\mathrm{mg} / \mathrm{L})\end{array}$ \\
\hline Daun jambu biji 0,0 g/l & 28,03 & 6,3 & 7,5 \\
Daun jambu biji 1,0 g/1 & 28,06 & 6,0 & 7,2 \\
Daun jambu biji 1,5 g/l & 27,93 & 6,0 & 7,2 \\
Daun sirih 0,0 g/l & 27,83 & 6,3 & 7,6 \\
Daun sirih 1,0 g/l & 27,80 & 6,3 & 7,2 \\
Daun sirih 1,5 g/l & 27,93 & 6,0 & 7,3 \\
Daun pepaya 0,0 g/l & 28,06 & 6,3 & 6,8 \\
Daun pepaya 1,0 g/l & 28,00 & 6,0 & 7,5 \\
Daun pepaya 1,5 g/l & 27,76 & 6,3 & 6,8 \\
\hline
\end{tabular}

phenol dan turunannya yang dapat menghambat pertumbuhan bakteri Staphylococcus aureus. Penelitian Herawati (2009) menunjukkan bahwa pengobatan ikan yang terkena parasit dengan cara perendaman menggunakan ekstrak daun sirih (Piper betle) dapat menghambat berkembang biaknya parasit Ichthyophthirius multifilis. Menurut Tim Karya Tani Mandiri (2009), daun sirih (Piper betle) mempunyai banyak manfaat baik itu akar, daun dan bijinya. Daun sirih (Piper betle) mengandung minyak atsiri yang memiliki bau yang aromatik dan berasa pedas, atsiri di daun sirih (Piper betle) mengandung chanivol $\mathrm{C} 4 \mathrm{H} 3 \mathrm{OH}$.

Sedangkan pada perlakuan ekstrak daun pepaya (Carica papaya) menunjukkan bahwa nilai intensitas dan prevalensi tertinggi pada konsentrasi $0 \mathrm{~g} / \mathrm{l}$ dan terendah pada perlakuan konsentrasi 1,0 g/l. Menurut Wardani (2012), daun pepaya (Carica papaya) mengandung sejumlah komponen aktif yang dapat meningkatkan kekuatan total antioksidan di dalam tubuh. Daun pepaya (Carica papaya) mengandung enzim papain, alkaloid karpain, pseudo karpain, glikosida, karposid dan saponin, dimana senyawa yang khas pada ekstrak daun pepaya yaitu papain. Flavonoid memiliki sifat sebagai anti mikroba karena flavonoid dapat membentuk senyawa kompleks dengan protein ekstraseluler terlarut dan dinding sel mikroba. Flavonoid juga memiliki sifat sebagai antibakteri dan antioksidan yang bekerja dengan meningkatkan sistem kerja dari imun, dimana leukosit sebagai pemakan antigen lebih cepat dihasilkan dan lebih cepat mengaktifkan sistem limfoid (Anonim, 2007 dalam Haryani, 2012).

Dari hasil penelitian menunjukkan bahwa perlakuan yang diberikan ekstrak daun pepaya dapat menghambat infeksi ektoparasit. Hal ini sesuai dengan perkataan Harborne (1987) dalam Haryani (2012), yang mengatakan bahwa kemampuan daun pepaya dalam menyembuhkan luka karena terdapat senyawa saponin. Senyawa saponin mempunyai sistem kerja dalam pembentukan kolagen, yaitu struktur protein yang bekerja dalam penyembuhan luka.

\section{Intensitas Ikan Karper (Cyprinus carpio)}

Hasil penelitian menunjukkan bahwa intensitas parasit Gyrodactylus sp., parasit Trichodina sp. dan parasit Ichthyophthirius multifilis tidak berbeda nyata setiap perlakuan. Ekstrak yang dapat menurunkan tingkat serangan ektoparasit pada ikan karper (Cyprinus carpio) yaitu ekstrak daun pepaya berdasar hasil penelitian. Menurut Wardani (2012), daun papaya mengandung sejumlah komponen aktif yang dapat meningkatkan total antioksidan di dalam tubuh. Tietze (1997) dalam Rehena (2010) mengatakan bahwa daun pepaya mengandung senyawa alkaloid karpain, caricaksatin, violaksantin, papain, saponin, flavonoida, politenol dan saponin. Selain itu, daun papaya juga mengandung protein yang tinggi, lemak, vitamin, kalsium (Ca) dan zat besi $(\mathrm{Fe})$ yang berfungsi dalam pembentukan hemoglobin.

\section{Tingkat Kelangsungan Hidup}

Berdasarkan hasil penelitian, perlakuan yang diberikan ekstrak daun dengan 
konsentrasi 1,5 g/l rata-rata kelangsungan hidupnya (SR) ikan karper (Cyprinus carpio) paling sedikit yaitu pada perlakuan ekstrak daun sirih. Hal ini sesuai dengan perkataan Achmad (2009) bahwa semakin besar ekstrak daun yang diberikan dalam pengendalian penyakit semakin besar reaksi yang ditimbulkan namun dapat mempengaruhi tingkat kelangsungan hidup ikan, karena semakin banyak ekstrak yang diberikan akan mempengaruhi sistem pernafasan ikan. Perlakuan kontrol yang tidak diberikan ekstrak dapat mempengaruhi tingkat kelangsungan hidup ikan karper (Cyprinus carpio) dan diduga pada perlakuan ini ikan karper banyak yang terserang parasit sehingga kelangsungan hidupnya sangat rendah.

\section{Pertumbuhan}

Hasil penelitian menunjukkan bahwa pemberian ekstrak daun jambu biji (Psidium guajava), daun pepaya (Carica papaya) dan daun sirih (Piper betle) tidak berpengaruh terhadap pertumbuhan ikan karper (Cyprinus carpio). Menurut Effendi (1997) dalam Sulaswesty (2014), faktor luar yang mempengaruhi pertumbuhan ikan yaitu suhu dan makanan, tetapi pada daerah tropik makanan menjadi faktor utama dalam pertumbuhan daripada suhu.

\section{Kualitas Air}

Data kualitas air (DO, pH dan suhu) selama penelitian dapat dilihat pada Tabel 6 . Pada Tabel 6. rata-rata suhu selama penelitian menunjukkan suhu yang relatif sama, yaitu antara $27^{\circ} \mathrm{C}$ sampai $28^{\circ} \mathrm{C}$ dimana suhu tertinggi pada perlakuan daun pepaya $0,0 \mathrm{~g} / \mathrm{l}$ dan daun jambu biji $1,0 \mathrm{~g} / \mathrm{l}$, sedangkan rata-rata suhu terendah pada perlakuan daun pepaya $1,0 \mathrm{~g} / 1$ yaitu $28^{\circ} \mathrm{C}$. Menurut Mantau (2004), suhu yang optimal untuk pertumbuhan ikan karper (Cyprinus carpio) sekitar $20^{\circ} \mathrm{C}-30^{\circ} \mathrm{C}$.

Rata-rata $\mathrm{pH}$ selama optimal antara 6,0 sampai 6,3. $\mathrm{pH}$ terendah pada perlakuan daun jambu biji 1,0 g/l, daun jambu biji 1,5 g/l, daun sirih 1,5 $\mathrm{g} / \mathrm{l}$ dan daun pepaya $1,0 \mathrm{~g} / \mathrm{l}$, sedangkan $\mathrm{pH}$ tertinggi pada perlakuan daun jambu biji $0,0 \mathrm{~g} / \mathrm{l}$, daun sirih $0,0 \mathrm{~g} / \mathrm{l}$, daun sirih $1,0 \mathrm{~g} / \mathrm{l}$, daun pepaya $0,0 \mathrm{~g} / \mathrm{l}$ dan daun pepaya $1,5 \mathrm{~g} / \mathrm{l}$. Nilai $\mathrm{pH}$ selama penelitian masih berada dalam nilai yang optimal $(6,0-6,3)$. Hal tersebut sesuai dengan Silaban (2012) bahwa pH yang optimal untuk pertumbuhan ikan karper (Cyprinus carpio) antara 6-8. DO selama penelitian juga masih dalam nilai yang optimal (6,8-7,6 mg/L). Hal tersebut sesuai pendapat Rudiyanti (2009) bahwa DO optimal untuk pertumbuhan ikan karper (Cyprinus carpio) antara $6,5 \mathrm{mg} / \mathrm{L}$ sampai $8,5 \mathrm{mg} / \mathrm{L}$.

\section{Kesimpulan}

Ekstrak daun jambu biji dan daun sirih memberikan pengaruh yang tidak signifikan terhadap prevalensi dan intensitas ektoparasit yang menyerang ikan karper (Cyprinus carpio), sedangkan ekstrak daun pepaya dengan konsentrasi 1,0 g/l menunjukkan hasil yang signifikan terhadap pervalensi dan intensitas ektoparasit pada ikan karper

\section{Daftar Pustaka}

Achmad, S. Ido ( 2009). Pengujian Aktivitas Ekstrak Daun Sirih (Piper betle Linn) terhadap Rhizoctonia sp. secara In Vitro. Departemen Manajemen Hutan, Fakultas Kehutanan, Institut Teknologi Bogor. Bogor. Bul. Littro Vol. 20, No.1, 2009, 92-98.

Devi, A.R. (2015). Pengawetan Ikan Nila (Oreochromis niloticus) Menggunakan Daun Sirih dengan Variasi Lama Perendaman yang Berbeda. Skripsi. Program Studi Pendidikan Biologi, Fakultas Keguruan dan Ilmu Pendidikan, Universitas Muhammadiyah Surakarta.

Haryani, A., G. Roffi, D. Ibnu, S . Ayi (2012). Uji Efektivitas Daun Pepaya (Carica papaya) untuk Pengobatan Infeksi Bakteri Aeromonas hydrophila pada Ikan Mas Koki (Carassius auratus). Fakultas Perikanan dan Ilmu Kelautan, Unpad. Jawa Barat. Bandung. Jurnal Perikanan dan Kelautan Vol. 3, No.3 : 213-220.

Herawati, V.E. (2009). Pemanfaatan Daun Sirih (Piper betle) untuk Menanggulangi Serangan Ektoparasit pada Ikan Hias Tetra. Staf Pengajar Jurusan Perikanan, Fakultas Perikanan dan Ilmu Kelautan, Universitas Diponegoro. Semarang. PENA Akuatik, volume 1 nomer 1. Inayatullah, S. (2012). Efek Ekstrak Daun Sirih Hijau (Piper betle L.) terhadap Pertumbuhan Bakteri Straphylococcus 
aureus. Skripsi. Program Studi Pendidikan Dokter, Fakultas Kedokteran dan Ilmu Kesehatan, Universitas Islma Negeri Syarif Hidayatullah. Jakarta.

Mantau, Z., J.B.M. Rawung, Sudarty. (2004). Pembenihan Ikan Mas yang Efektif dan Efisien. Balai Pengkajian Teknologi Pertanian Sulawesi Utara. Manado. Jurnal Litbang Pertanian, 23(2), 2004

Nurcahyo, W. (2014). Parasit pada Ikan. Gajah Mada University Press. Jakarta.

Rehena, F. Johanis (2010). Uji Efektivitas Ekstrak Daun Pepaya (Carica papaya LINN) sebagai Antimalaria In Vitro. Fakultas Keguruan dan Ilmu Pendidikan, Universitas Patimura. Jurnal ILMU DASAR vol. 11, no.1, Januari 2010 : 96-100.

Rosidah, M.A. Wila (2012). Potensi Ekstrak Daun Jambu Biji sebagai Antibakterial untuk Menanggulangi Serangan Bakteri Aeromonas hydrophila pada Ikan Gurame (Osphronemus gouramy). Fakultas Perikanan dan Ilmu Kelautan, Universitas Padjajaran. Jawa Barat. Jurnal Akuatik Vol.3, No.1. hlm 19-27.

Rudiyanti, S., D.E. Astri. (2009). Pertumbuhan dan Survival Rate Ikan Mas (Cyprinus carpio Linn) pada Berbagai Konsentrasi Pestisida Regent 0,39. Program Studi Manajemen Sumberdaya Perairan, Jurusan Perikanan, Fakultas Perikanan dan Ilmu Kelautan, Universitas Diponegoro. Semarang. Jurnal Saintek Perikanan vol. 5, no.l, hlm : 39-47.

Silaban, F. Tio,S. Limin, Suparmono. (2012). Dalam Peningkatan Kerja Filter Air untuk Menurunkan Konsentrasi Amonia pada Pemeliharaan Ikan Mas (Cyprinus carpio). Jurusan Budidaya Perairan, Fakultas Pertanian, Universitas Lampung. Lampung. Jurnal Rekayasa dan Teknologi Budidaya Perairan, vol. 1, no.1.

Sulawesty, F., C. Tjandra, M. Endang. (2014). Laju Pertumbuhan Ikan Mas (Cyprinus carpio L.) dengan Pemberian Pakan Lemnal (Lemna perpusilla TORR.) Segar pada Kolam Sistem Aliran Tertutup. Pusat Penelitian Limnologi-LIPI. LIMNOTEK (2014) 21 (2) : 177-184.

Tim Karya Tani Mandiri. (2009). Pedoman Budidaya : Beternak Ikan Mas. CV. Nuansa Aulia Bandung. Jawa Barat.
Umara, A., B. Muttaqien., H. Muhammad. (2014). Identifikasi Parasit pada Ikan Gabus (Channa striata) Di Desa Meunasah Manyang Lamlhon Kecamatan Lhoknga Aceh Besar. Program Studi Pendidikan Dokter Hewan, Fakultas Kedokteran Hewan, Universitas Syiah Kuala, Banda Aceh. Aceh. Jurnal Medika Veterinaria, vol.8, no.2 Agustus 2014.

Wardani, F.R. (2012). Potensi Perasan Daun Pepaya (Carica papaya) terhadap Jumlah Makrograf Pasca Gingivektomi pada Tikus Wistar Jantan. Skripsi. Fakultas Kedokteran Gigi, Universitas Jember. Jawa Timur.

Winaruddin, Eliawardani. (2007). Inventarisasi Ektoparasit yang Menyerang Ikan Mas (Cyprinus carpio) yang Dibudidaya dalam Jaring Apung Di Danau Laut Tawar Kabupaten Aceh Tengah. Laboratorium Parasitologi, Fakultas Kedokteran Hewan, Universitas Syiah Kuala, Banda Aceh. Aceh. J. Ked. Hewan Vol.1, No.2 September 2007. 